Bangladesh J. Zool. 49(1): 57-68, 2021

ISSN: 0304-9027

eISSN: 2408-8455

\title{
MONTHLY VARIATION OF BENTHIC FAUNA IN RELATION TO WATER QUALITY OF RAJDHALA BEEL, NETROKONA
}

\author{
Gulshan Ara Latifa ${ }^{1, *}$, Mst. Mahmuda Parvin ${ }^{2}$ and Md. Shahidul Islam ${ }^{1}$ \\ Department of Zoology, University of Dhaka, Dhaka 1000, Bangladesh
}

\begin{abstract}
The knowledge on benthic fauna is important to know the biological interactions of the ecosystem. Abundance and composition of benthos along with some physico-chemical parameters of water of Rajdhalabeel, Netrokona was carried out from May 1998 to April 1999. The water parameters varied between or within the months but they did not vary from location to location. The benthic organisms had fluctuated both quantitatively and qualitatively. Considerable variation of benthos was detected during the period of the study. The composition of benthos were $38.26 \%, 29.86 \%$ and $25.22 \%$ for molluscs, oligochaetes and chironimids respectively. The highest number $\left(1310.98 \mathrm{ind} / \mathrm{m}^{2}\right)$ was recorded in July, 1998 while it was lowest (333.3 ind $\left./ \mathrm{m}^{2}\right)$ in April, 1999.The study revealed the beel as productive one and implementation of a little development work, good management and protect fishes from poaching may turn the beel into a very good fish resource.
\end{abstract}

Key word: Benthos, beel, monthly variation, physicochemical parameter

\section{INTRODUCTION}

Bangladesh is enriched with extensive fishery resources both, inland and marine with a wide variety of indigenous and exotic fish faunas. The beels are large surface water bodies that accumulate the surface runoff water through internal drainage channels. These depressions are mostly formed by erosions and are seen all over our country (Islam et al., 2010). Beels are naturally rich in fisheries resources. Beels are most productive for aquatic flora and fauna (Ahmed, 1996). Beels and floodplains are the main source of our fish supplies in the country. The benthic macro-invertebrates live in the bottom sediments of a water body which constitute an important intermediate link between phytoplankton, zooplankton and the fish stock in the food chain (Buscemi, 1961). Benthic organisms are rich in amino acids, fatty acids, vitamins, minerals, etc. which supply complete diet for many bottom dwelling fishes and

\footnotetext{
* Author for Corresponding: <gulshan_al@yahoo.com>, 2Department of Environmental Science, Stamford University of Bangladesh, Dhaka, Bangladesh

(C)2021 Zoological Society of Bangladesh DOI: https://doi.org/10.3329/bjz.v49i1.53682
} 
catfishes. Benthos is also an indicator of productivity of a water body (Dewan, 1973; Latifa et al, 1997). Assessment of monthly abundance of benthos may lead to assessment of bio-nutrient status of productivity in an aquatic habitat (Hasan et al., 2016).There are many beels and lakes in our country where a little management system is prevailing to improve the biological conditions of them.

Benthos organisms are also essential food items for cultivation of introduced fisheries in the managed water bodies (Oven, 1958). The abundance distribution varies with depth (Habib et al., 1984) in relation to physico-chemical factors (Ali et al.,1978) and also with the change of seasons (Ali et al., 1981).

Rajdhala Beel is a moderate perennial water body at Purbadhala in Netrokona. The Beel was important for its fisheries resources. Due to various natural and anthropogenic activities, the beel habitat has been deteriorated resulting in the fish production from the beel. That's why the overall objective of the present study was to generate baseline information on the water quality and benthic productivity of the beel. However, the specific objectives were:

- To monitor the water quality parameters (temperature, water depth, secchi depth, $\mathrm{p}^{\mathrm{H}}$, dissolved oxygen, carbon dioxide, hardness, alkalinity, ammonia, and nitrite) of the beel on a month basis.

- To investigate the qualitative and quantitative information on benthos.

\section{MATERIAL AND METHODS}

Study Area: A natural water body, named RajdhalaBeel is situated $20 \mathrm{~km}$ north from Netrokona (Fig.1). There are four villages around the beel. The Rajdhalabeel at Purbadhala, Netrakonawith an area of about 53 ha $\left(24^{\circ} 70^{\prime}\right.$ to $25^{\circ} 80^{\prime} \mathrm{N}$ and $90^{\circ} 29^{\prime}$ to $90^{\circ} 48^{\prime} \mathrm{E}$ ) is an important reservoir with rich ichthyofauna. The beel which is a moderate perennial water body and an oval shaped depression capable of retaining water depth of about 4.7 to $7.7 \mathrm{~m}$ throughout the year (Rahman et al., 2008).

Sampling Procedure: The climatic data of the study was collected from the Meteorological Department, Government of Bangladesh, Agargaon, Dhaka. The local weather station is situated in Mymensingh. They collect the data and transfer to central recording section in Dhaka. Data used for the present study were air temperature, photoperiod and rainfall. Sampling of water and benthos were collected from three different stations of the Rajdhalabeel monthly all the year round.

The water samples were collected from the Rajdhalabeel to determine water temperature, transparency, color, $\mathrm{pH}$, dissolved oxygen (DO), alkalinity, hardness, free carbon dioxide, nitrate-nitrogen $\left(\mathrm{NO}_{3}-\mathrm{N}\right)$, ammonia-nitrogen $\left(\mathrm{NH}_{3}-\right.$ $\mathrm{N}$ ), etc. Mostly $\mathrm{HACH}$ Kit (Model $\mathrm{FF} \mathrm{HaCH}$ ) was used to determine the water 
quality parameter of Rajdhahabeel. In case of benthic fauna Mollusca, Oligochaetes, Chironomids and other organisms (Culicinae and insect larvae) were measured by sieve method.
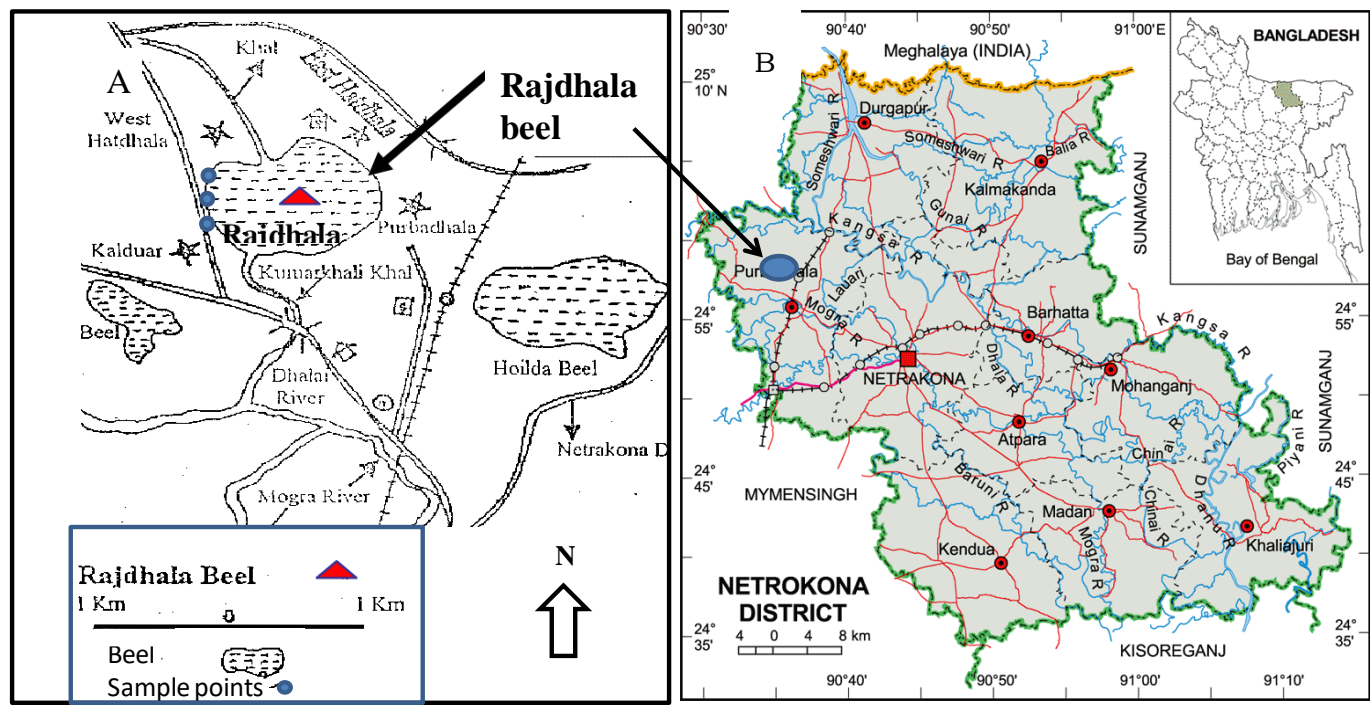

Fig. 1 Study Area (A-Shape of the beel with sample points and B-Location of the beel in Nentrokona district).

\section{RESULTS AND DISCUSSION}

The climatic factors and water quality parameters affects the growth and abundance of benthos. These also affect the growth and production of fish and other aquatic organisms. The standard water quality parameters are the prerequisites for healthy aquatic environment. The primary productivity of water body mainly depends on physical, chemical and other factors of the environment (Rahmanet al., 1992).

Climatic Factors: The average air temperature, average monthly photoperiod and total monthly rainfall of the study area were measured as climatic factors. The major groups of climatic data such as air temperature, photoperiod, rainfall etc were presented in table 1.

Air Temperature: Air temperature was higher in summer due to the strong intensity of light and gradually decreased from September, 1998 to January, 1999 (Table1). The highest and lowest temperature was $30.4^{\circ} \mathrm{C}$ and $18.8^{\circ} \mathrm{C}$ in August and January, respectively. Temperature is one of the main controlling 
factors of biological properties in living organisms. This is due to the breeding time is associated with seasonal variations (Michael, 1968).

Table 1 Climatic data of Rajdhalabeel, Netrokona

\begin{tabular}{cccc}
\hline $\begin{array}{c}\text { Months/ } \\
\text { parameter }\end{array}$ & $\begin{array}{c}\text { Air Temperature } \\
\left.\mathbf{(}^{\circ} \mathbf{C}\right)\end{array}$ & $\begin{array}{c}\text { Photoperiod } \\
\text { (hours) }\end{array}$ & Rainfall(mm) \\
\hline May'98 & 28.9 & 5.7 & 299 \\
June & 29.3 & 3.9 & 176 \\
July & 29 & 2.1 & 755 \\
Aug & 30.4 & 2.4 & 517 \\
Sep & 29 & 5.0 & 270 \\
Oct & 28 & 7.1 & 50 \\
Nov & 25.7 & 7.5 & 31 \\
Dec & 24 & 8.6 & 0 \\
Jan'99 & 18.8 & 7.8 & 0 \\
Feb. & 23.5 & 8.7 & 0 \\
Mar & 23.2 & 8.5 & 1 \\
April & 27.5 & 7.2 & 108 \\
\hline
\end{tabular}

Photoperiod: Photoperiod was longer during winter and shorter in summer. The rise in photoperiod time increase in rate in photosynthesis and dissolved oxygen. Very short photoperiod with heavy rainfall causes the killing of fishes in many ponds in our country due to lake of dissolved oxygen in water for short photosynthesis and high content of $\mathrm{CO}_{2}$ in water (Habib et al., 1984) in July was found in table 1 .The table also revealed that it was increased with low rainfall in December to April during the study period.

Rainfall: Heavy rainfall was $755 \mathrm{~mm}$ occurred in July and few or rainless (December, January and February) in winter due to monsoon breeze from the Bay of Bengal with high content of water vapor. Increased high volume of water associated with decreasing of $\mathrm{p}^{\mathrm{H}}$ in water. Rainwater drains suspended particles and washed off from the nearby area and vegetations start to die in the huge volume of water. Benthos also decline due to high volume of water (Dineen, 1953).

Physico-chemical factors: Monthly variation of the physico-chemical factors were observed from the study area (Table 2 and 3).

Water Temperature: Water temperature was observed higher than the air temperature during the study period. The highest and lowest temperatures were found to be $31^{\circ} \mathrm{C}$ and $22.6^{\circ} \mathrm{C}$ in May, 1998 and January, 1999, respectively. The data of water temperature showed close relationship with the air temperature. Water temperature was found to increase with an increase in air temperature and vice-versa. Similar results were also reported by Chowdhury et al., 1989. Odum (1953) described water temperature as one of the limiting factors of the 
aquatic ecosystem. Water temperature is the most important parameter that has profound direct and indirect effects (Welch, 1958).

Table 2 Physical parameter of Rajdhala beel

\begin{tabular}{|c|c|c|c|c|c|c|c|c|c|c|c|c|}
\hline $\begin{array}{l}\text { Month/ } \\
\text { Parameter }\end{array}$ & $\begin{array}{l}\text { May' } \\
98\end{array}$ & Jun & Jul & Aug & Sep. & Oct. & Nov. & Dec. & $\begin{array}{l}\text { Jan' } \\
99\end{array}$ & Feb. & $\begin{array}{l}\text { Marc } \\
\text { h }\end{array}$ & April \\
\hline $\begin{array}{l}\text { Water } \\
\text { Temperature }\end{array}$ & 31.0 & 30.0 & 29.0 & 29.4 & 29.8 & 29.4 & 27.7 & 25.0 & 22.6 & 30.0 & 29.6 & 29.0 \\
\hline Color & $\begin{array}{l}\text { Gree } \\
\text { nish }\end{array}$ & $\begin{array}{l}\text { Gree } \\
\text { nish }\end{array}$ & $\begin{array}{l}\text { Turbi } \\
\text { d }\end{array}$ & $\begin{array}{l}\text { Turb } \\
\text { id }\end{array}$ & $\begin{array}{l}\text { Turb } \\
\text { id }\end{array}$ & $\begin{array}{l}\text { Brow } \\
\text { nish }\end{array}$ & $\begin{array}{l}\text { Gree } \\
\text { nish }\end{array}$ & $\begin{array}{l}\text { Brown } \\
\text { ish }\end{array}$ & $\begin{array}{l}\text { Brow } \\
\text { nish }\end{array}$ & $\begin{array}{l}\text { Brow } \\
\text { nish }\end{array}$ & $\begin{array}{l}\text { Brow } \\
\text { nish }\end{array}$ & $\begin{array}{l}\text { Green } \\
\text { ish }\end{array}$ \\
\hline Transparency $(\mathrm{cm})$ & 45.0 & 40.0 & 39 & 40.1 & 44.7 & 47.1 & 50.4 & 54.0 & 62.5 & 63.0 & 72.1 & 69 \\
\hline Water Depth(m) & 4.27 & 4.42 & 4.42 & 5.24 & 7.0 & 4.66 & 4.72 & 4.05 & 3.96 & 3.87 & 3.67 & 3.72 \\
\hline
\end{tabular}

Table 3 Chemical parameter of Rajdhala Beel

\begin{tabular}{|l|l|l|l|l|l|l|l|l|l|l|l|l|}
\hline $\begin{array}{l}\text { Month/ } \\
\text { Parameter }\end{array}$ & May'98 & Jun & Jul & Aug & Sep & Oct & Nov & Dec & $\begin{array}{l}\text { Jan'9 } \\
\mathbf{9}\end{array}$ & Feb & Mar & April \\
\hline pH & 7.5 & 7.3 & 7.4 & 7.5 & 7.4 & 7.6 & 7.7 & 8.0 & 7.6 & 8.0 & 8.4 & 8.5 \\
\hline DO, mg/1 & 4.8 & 5.0 & 6.2 & 5.9 & 10.1 & 9.7 & 6.8 & 9.2 & 9.0 & 8.8 & 8.9 & 9.0 \\
\hline CO2, mg/l & 5.0 & 4.8 & 4.8 & 4.9 & 3.5 & 3.3 & 5.0 & 2.8 & 2.9 & 4.0 & 3.5 & 3.0 \\
\hline $\begin{array}{l}\text { Alkalinity, } \\
\text { mg/1 }\end{array}$ & 96.0 & 80.1 & 64.4 & 82.8 & 100.3 & 98.0 & 98.3 & 101.2 & 99.8 & 99.8 & 98.04 & 91.2 \\
\hline $\begin{array}{l}\text { Hardness, } \\
\text { mg/l }\end{array}$ & 62.0 & 61.1 & 51.3 & 61.6 & 104.9 & 92 & 94.05 & 89.8 & 100.3 & 96.9 & 100.32 & 108.3 \\
\hline $\begin{array}{l}\text { Ammonia } \\
\text { mg/l, }\end{array}$ & 0.21 & 0.017 & 0.016 & 0.017 & 0.026 & 0.025 & 0.03 & 0.23 & 0.23 & 0.22 & 0.23 & 0.22 \\
\hline $\begin{array}{l}\text { Nitrate, } \\
\text { mg/1 }\end{array}$ & 0.07 & 0.016 & 0.17 & 0.18 & 0.07 & 0.07 & 0.07 & 0.07 & 0.066 & 0.066 & 0.066 & 0.066 \\
\hline
\end{tabular}

Transparency: The transparency is the measure of plankton, organic debris, silt, dust, flood water and other particles. The higher value of transparency represents less number of plankton and suspended materials present in water. The secchi depth for transparency was found to fluctuate from a maximum of $72.1 \mathrm{~cm}$ in March'99 to a minimum of $39 \mathrm{~cm}$ in July'98. Water transparency is generally related to plankton abundance and a transparency of between 15-40 $\mathrm{cm}$ is suitable for fish culture (Boyd, 1982).

Water Depth: Water body should not be shallower than $3 \mathrm{ft}$, deeper than $15 \mathrm{ft}$ and optimum depth should be $6 \mathrm{ft}$. The water depth of the beel ranged from $7.0 \mathrm{~m}$ to $3.67 \mathrm{~m}$. The maximum was in September and minimum in March ' 99 . Maximum depth of water in September was also recorded by Ehshan et al., (1997) from Chanda Beel, but they found minimum water depth in winter season.

Color: Color of the beel varied between greenish, brownish to turbid. Most of the time color was greenish to brownish. The color of the water was turbid in the months of the July, August and September. 
$p H: \mathrm{p}^{\mathrm{H}}$ is a measure of the acid or alkaline condition of water. Generally aquatic plants and animals are adapted to a specific $\mathrm{p}^{\mathrm{H}}$ range. Natural populations may also be harmed by water that is too acidic or alkaline. Immature stages of aquatic insects and young fish are extremely sensitive to $\mathrm{p}^{\mathrm{H}}$ values below 5. Even microorganisms present in the bottom sediment cannot live in high acidic conditions. Metals bound to organic matter and sediment are released into water at high acidic conditions. Especially phytoplankton and other aquatic vegetation remove carbon dioxide from the water during photosynthesis, so the $\mathrm{p}^{\mathrm{H}}$ of a water body rises during the day and decreases during the night (Boyd et al., 1984). Ehshan et al. (1997) observed a neutral pH throughout the study period in Chandabeel. The highest $\mathrm{p}^{\mathrm{H}}$ value was recorded in April and lowest in June (Table 3). That means $\mathrm{p}^{\mathrm{H}}$ of the beel ranges from 7.3 to 8.5 which is a good agreement with the standard value of inland surface water (Table 4). Most species can't survive at a $\mathrm{p}^{\mathrm{H}}$ of 4 or below it and a $\mathrm{p}^{\mathrm{H}}$ of 11 or higher.

Dissolved Oxygen (DO): Dissolved oxygen is an important water quality parameter for all aquatic organism. It is a measures of the amount of gaseous oxygen $\left(\mathrm{O}_{2}\right)$ dissolved in an aqueous solution. Oxygen gets into water by diffusion from the surrounding air, by aeration (rapid movement), and as a waste product of photosynthesis. It depends on the physical, chemical and biological activities in the water body (Huq et al., 2005). Dissolved oxygen levels of 5 to $6 \mathrm{mg} / 1$ are usually required for most of the aquatic organisms. Table 3 reveals that DO level ranges from 4.8 to $10.1 \mathrm{mg} / 1$ during the study period. The highest values were found in the late autumn, winter and spring and the minimum in summer. These data are in good agreement with report of Welch (1958), and Chawdhury and Mazumder (1981). It is assumed that this is due to longer photosynthesis period in winter than summer. DO has direct relationship with water temperature, increase of water temperature shows decreases oxygen content in water (Byod, 1982) and Ali et al,.1982. DO showed an inverse relationship with $\mathrm{p}^{\mathrm{H}}$ in the study area and similar result was also reported by Chowdhury and Mazumder (1982).

Free Carbon dioxide: The free carbon dioxides ranged from $2.8 \mathrm{mg} / 1$ to 5.0 $\mathrm{mg} / \mathrm{l}$. The maximum carbon dioxide content was found in May and November, and the minimum was in the month of December. The maximum amount was found in summer when photoperiod is short. Shaha et al., 1971 and Habib et al,.1984 also reported similar observations. Carbon dioxide shows inverse relationship with temperature. Probably sunlight is related to both increases in temperature and photosynthesis. 
Total Alkalinity: Alkalinity commonly means the concentration of carbonate, bi-carbonate and hydroxide ions in water expressed as $\mathrm{CaCO}_{3}$. In alkaline water essential nutrients are found in higher ranges because of higher biological productivity. According to Alikuhni (1957) total alkalinity of more than $100 \mathrm{ppm}$ is required for highly productive water bodies. The changes in alkalinity values occurred with the changes in hardness levels. The total alkalinity concentrations ranged from (101.2-64.4) $\mathrm{mg} / 1$ in the months of December and July respectively. The relatively higher values were observed in winter. This finding is observed in the winter. This finding is agreed with George (1966). Ali et al., 1981 showed a wide range of fluctuation in the value of alkalinity. In the winter water decreases in the volume and concentration of $\mathrm{CaCO}_{3}$ increases in water that might be responsible for the increased alkalinity during winter.

Hardness: Total hardness means the cataion concentration. The hardness level of 170-22 mg/1 is termed as good quality water (Khan et al.,1990). Hardness ranged from (108.3-51.3)mg/1 in April and July respectively. Mukharjee and Bhattacharjee (1949) also observed sharp fall in total hardness during monsoon due to heavy rainfall resulting in dilution of water. A highly significant and direct correlation was found between total hardness and alkalinity. These findings were also similar to Boyd (1982). Total hardness might also be related to increasing photosynthetic activities as observed by George (1966) and Dewan (1973).

Ammonium: It mainly present in water as ammonium ion $\left(\mathrm{NH}_{4}^{+}\right)$. The sum of unionized ammonia and ammonium is called total ammonia nitrogen (Boyd, 1982). The concentration of ammonia was ranged from (0.23-0.016) $\mathrm{mg} / 1$. The value of ammonia was observed higher in spring and summer. This may be due to the high rate of organic decomposition. Welch (1958) also showed such relationship for surface water. In the study area also showed direct relationship with $\mathrm{p}^{\mathrm{H}}$ which was complied with Boyd (1982).

Table 4 Standards for inland surface water quality

\begin{tabular}{lccc}
\hline Purpose of using inland surface water & pH & $\begin{array}{c}\text { DO } \\
\text { (mg/L) }\end{array}$ & $\begin{array}{c}\text { BOD } \\
\text { (mg/L) }\end{array}$ \\
\hline Water usable for recreational/drinking purpose & $6.5-8.5$ & 5 or more & 3 or less \\
Water usable by fisheries & $6.5-8.5$ & 5 or more & 6 or less \\
\hline
\end{tabular}

(Source: ECR, 97)

Nitrite: It is the partially reduced form of nitrate and is usually present in insignificant amounts (Goldman and Horne, 1983). Insignificant amounts of nitrate were recorded during the study period. There was no remarkable change 
in seasonal variation but relatively higher values were found in autumn. An imbalance in nitrification reaction leads to the accumulation of nitrite (Boyd, 1982). The concentration of nitrite in the beel was very low. It was ranged from (0.016 - 0.18) $\mathrm{mg} / 1$.

Table 5 Monthly abundance (Average) of benthic fauna (ind $/ \mathrm{m}^{2}$ )

\begin{tabular}{llllcl}
\hline Groups/Months & \multicolumn{1}{c}{ Mollusca } & Oligochaeta & Chironomids & Others & $\begin{array}{c}\text { Grand } \\
\text { Total }\end{array}$ \\
\hline May'98 & $311.09 \pm 44.43$ & $266.64 \pm 44.44$ & $177.76 \pm 44.44$ & 0 & 755.49 \\
June & $222.21 \pm 44.5$ & $177.77 \pm 88.89$ & $133.32 \pm 0$ & 0 & 533.3 \\
July & $777.7 \pm 22.27$ & $377.74 \pm 199.98$ & $155.54 \pm 22.22$ & 0 & 1310.98 \\
August & $177.7 \pm 44.44$ & $177.76 \pm 44.44$ & $111.1 \pm 66.66$ & $22.22 \pm 22.22$ & 488.78 \\
September & $133.32 \pm 0$ & $199.98 \pm 22.22$ & $155.54 \pm 22.22$ & 0 & 488.84 \\
October & $266.64 \pm 133.32$ & $177.76 \pm 44.44$ & $133.32 \pm 44.44$ & $44.44 \pm 44.44$ & 622.16 \\
November & $244.44 \pm 22.22$ & $111.1 \pm 22.22$ & $155.54 \pm 22.22$ & 0 & 511.08 \\
December & $177.76 \pm 0$ & $111.1 \pm 66.66$ & $244.42 \pm 111.1$ & 0 & 533.28 \\
January'99 & $155.54 \pm 22.22$ & $266.64 \pm 44.44$ & $133.32 \pm 0$ & $66.66 \pm 66.66$ & 622.16 \\
February & $222.2 \pm 44.44$ & $177.76 \pm 88.88$ & $177.76 \pm 44.44$ & $22.22 \pm 22.22$ & 599.94 \\
March & $88.88 \pm 0$ & $199.98 \pm 66.66$ & $244.42 \pm 111.1$ & $333.3 \pm 111.1$ & 866.58 \\
April & $155.54 \pm 22.22$ & $44.44 \pm 0$ & $111.1 \pm 66.66$ & $22.22 \pm 22.22$ & 333.3 \\
Monthly Average & 244.41 & 190.72 & 161.10 & 42.59 & 638.82 \\
\hline
\end{tabular}

Benthic Fauna in Rajdhalabeel: The monthly average of the total benthic fauna was 638.82 ind $/ \mathrm{m}^{2}$ which showed the highest peak $\left(1310.98 \mathrm{ind} / \mathrm{m}^{2}\right)$ in July the lowest was recorded in April (333.3 ind $/ \mathrm{m}^{2}$ ) (Table 5). Benthic fauna was sorted as major groups of Mollusca, Oligochaetes as well as Chironomids and other organisms in descending order. In July all physico parameters were in favorable condition in Rajdhahabeel.

Mollusc: Mollusca was the most dominant group (38.26\%) among the total benthos in the beel (Fig. 3). The monthly average was $\pm 244.41 \mathrm{ind} / \mathrm{m}^{2}$. The highest peak was in July and lowest in March (Fig-2), The second highest peak was found in August. Important fauna were Bythinia, Viviparus, Pila and Lymnaea. Das et al., (1983) observed peak of molluscs also in July. Ali et al., (1978) recorded the abundance of molluscs in the month of August and October.

Oligochaeta: Oligochaetes were the second dominant group of the benthic fauna. Similar observation was also reported by Das et al., (1983). They were $29.86 \%$ of the total benthic fauna. The height peak of oligochaetes was recorded 
in July (377.74 ind $\left./ \mathrm{m}^{2}\right)$ and lowest in April (44.44 ind $\left./ \mathrm{m}^{2}\right)$. Similarly height peak of it also recorded by Das et al. (1983) in July but lowest in December. The higher percentage of oligochaetes in the beel might be due to favorable bottom mud and alkaline nature of the beel and huge aquatic vegetation that favored their growth. Mainly Nais, Tubifex, Limnodrilusetc fauna were found in the beel during the study period.

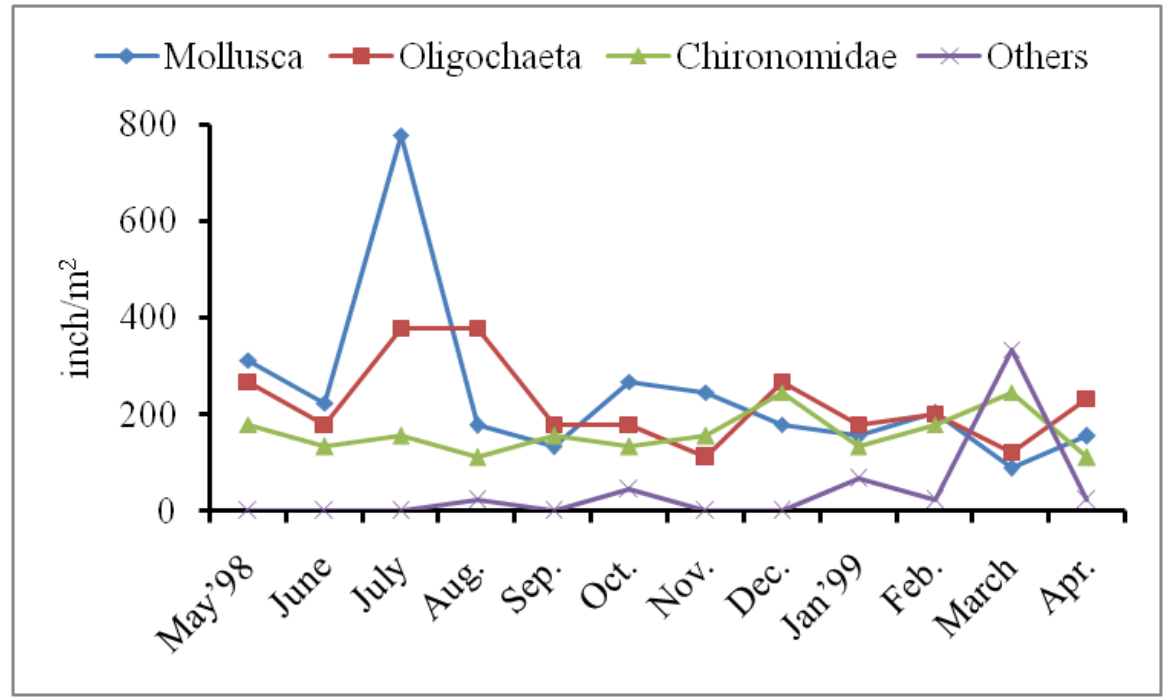

Fig.2. Monthly fluctuation of benthic fauna during the study period.

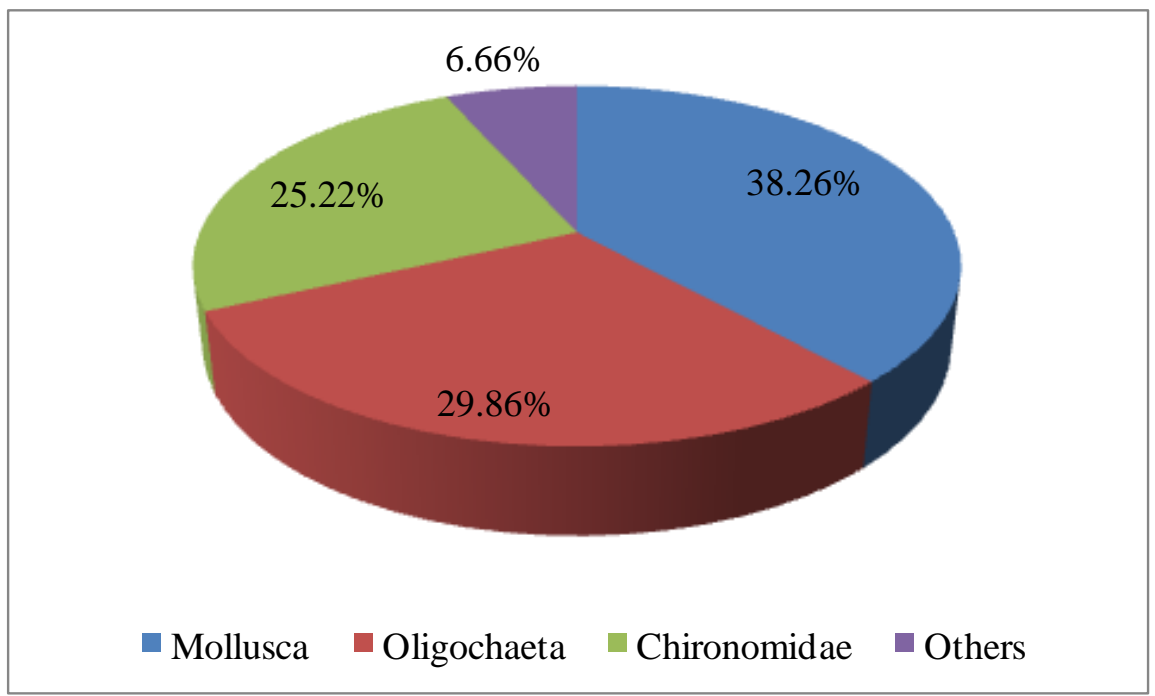

Fig.3. Monthly Percentage Occurrence of Benthic Fauna. 
Chironomids: Chironomid species was the third in position of dominancy which occurred 161.1 ind $/ \mathrm{m}^{2}$ of monthly average. This group showed highest peak in the month of December and March (244.42 ind $\left./ \mathrm{m}^{2}\right)$ and lowest (111.1 ind $/ \mathrm{m}^{2}$ ) in August and April. Das et al., (1983) also found the highest abundance of this group in December. Chironomid covered $25.22 \%$ of the benthos. The important fauna were Chironomus, tanypus and pelopia.

Other organisms: The miscellaneous group observed were culicine larvae, leeches, etc were not regular in occurrence in the samples of different months. Their monthly average was $42.59 \mathrm{ind} / \mathrm{m}^{2}$. Their maximum abundance was in March (333.3 ind $/ \mathrm{m}^{2}$ ) and minimum (22.22 ind $/ \mathrm{m}^{2}$ ) in the month of August, February and April. They were absent in the months of May to July and November to December.

\section{CONCLUSION}

The study revealed that the abundance of benthic fauna the molluscan sp., oligocheates, chironomid sp. and others were $38.26 \%, 29.86 \%, 25.22 \%$ and $6.66 \%$ respectively. It is evident from the results that of the benthos, when the oligochaete increases there is a reduction in chironomids and vice-versa. During the study period the physico-chemical parameters showed monthly variation but all were in acceptable limit. The situation has been changed and physicochemical parameters of the beel improved since the adoption of management policies.

\section{LITERATURE CITED}

AHMAD, M.N. and ISLAM, M.Z. 1996. Development management of fisheries resources on basis of open water fish culture in Bangladesh.MatshyaPakkha '96'. Ministry of Fisheries and Livestock, Govt. of Bangladesh.

ALIIKUHNI, K.H. 1957. Fish culture in India, Farm bull no.20, Indian coun. Arr. Res. New Delhi. 144 pp.

ALI, S., CHHOUDHURY, A.Q. and MAZUMDER, N. 1978.Studies on the population dynamics and benthic macroinvertibrates of a fish pond at Chadpur.Dhaka Uni. Stu. (B).26: 131-137.

ALI, S., RAHMAN, A. and MAJID, A. 1981.Studies on benthic macroinvertibrates.Proc.3rd Nat. Zool. Conf. Bangladesh.151-171.

BOYD, C.E. 1982. Water Quality Management for Pond Fish Culture. Elsevier, Amsterdam, 318.

BUSCEMI, P.A. 1961. Ecology of the bottom fauna of Parvin Lake, Colorado. Trans. Amer. Microse. Soc. 80(3): 266-307.

CHOWDHURY, A.N., BEGUM, S.and SULTANA, N. 1989.Occurance and seasonal variation of zooplankton in a fish pond in relation to some physico-chemical factors. Bangladesh $J$. Zool.17(2): 101-106. 
DAS. M and ISLAM, M.A. 1983. Study on macrobenthos of an artificial pond in the BAU campus. Bangladesh J. Aqua. 25(1): 1-11.

DINEEN, C.F. 1953. An ecological study in a Minnesota pond.Am.Nid. Net. 50:349-376.

DEWAN, S. 1973. Investigation into the ecology of fishes of Mymensingh Lake. Ph.D. Dissertation. Bangladesh Agri. Univ. Mymensingh. 235.

EHASHAN, M.A., HOSSAIN, M.S., MAZID, M.A., MOLLAH, M.F.A, RAHMAN, S. and RAZZAQUE, A. 1997. Limnology of Chandabeel.Bangladesh J. Fish Res.1(1): 31-40.

ECR.1997. The Environment Conservation Rules, Government of the People's Republic of Bangladesh, Ministry of Environment and Forest, 205-207.

GEORGE, M.G. 1966. Occurrence of permanent algal bloom in a fish tank in Delhi with special reference to factors responsible for its production.Proc. Ind. Acad. Sci. 61: 354-362.

GOLDMAN, C.R. and HORNE, A.J. 1983. Lomnology. McGraw-Hill Book Company NY, USA, pp 464.

HABIB, M. A.B, ISLAM M.A, MOHSHINUZZAMAN, M. and RAHMAN,M.S. 1984. Effect of some physiochemical parameters of water on the abundant and fluctuation of zooplankton of two selected ponds. Uni. J. Zool. Rajshahi Univ. 3: 27-34.

HASAN, R., AMIN, R. M., RAHMATUllAH, SM., AZAD, SM.O., MUKIT, S.S. and ROY, S. 2016. Monthly variations of benthic community in relation to hydrological parameters in the ponds of Bangladesh agricultural university, Bangladesh. Int. J. Fish and Aqua.Stu.4(5): 386-392.

HUQ, S.M.I. and ALAM, M.D.2005 A Handbook on Analysis of Soil, Plant and Water BACERDU, University of Dhaka, Bangladesh , xxii+246 pp.

ISLAM, M. S., RAHMAN, R. M., SHAHABUDDIN, A.K.M. and AHMED, R. 2010. Changes in wetlands in Dhaka City: Trends and physico-environmental consequences. J. Life Earth Sci. 5: 37-42.

LATIFA, G.A., CHOUDHURY, A. and SULTANA, R. 1997. Zonal variation and abundance of benthic macro invertebrates in relation to some physico-chemical parameters in fish cum chicken farm ponds. Bangladesh J. Zool. 25(2): 165-171.

RAHMAN, M.S. 1992. Water quality management in aquaculture.Publ. Bangladesh Rural Advancement Committee.7 pp.

RAHMAN, M.A. and HAUQUE, M.M. 2008. Beelfishery and livelihood of the local community in Rajdhala, Netrakona, Bangladesh.Bangladesh J, Fish. Res., 12(1): 95-108.

SHAHA, G.N., SEHGAL, S.I., MOITRA, E. and Nandy, A.C. 1971. Studies on seasonal and diurnal variation in physico-chemical and biological condition of perennial freshwater pond.J.Inland Fish. Soc. India.3: 79-102.

MICHAEL R.G.1968.Studies on the zooplankton of a tropical fish pond.Hydrobiol.32:47-68.

MUKHARJEE, D.P. and BHATTACHATARJEE, P. 1949. Study of spermatozoa from different levels of the male reproductive tracts of the sheep, goat and buffalo. Proceedings of the Zoological society of Bengal, 2:149-61.

ODUM, E.P. 1953. Fundamentals of ecology.Philadelphia: W. B. Saunders Company, 383 pp. 
OVEN, V.V.1958. Experiment of different stocking rates of the common carp, Cypinuscarpio (L.) in nursery ponds. Proc. Indo-Pacific Conn. 7(11):12-47.

WELCH, P.S. 1958.Limnology.2 $2^{\text {nd }}$ ed. McGraw-Hill Book Company, New York, USA 538 pp.

(Manuscript received on 18 October, 2020 revised on 26 November, 2020) 